\title{
Problem of Multinational Transnational Corporations under Covid-19
}

\author{
Tran Si Lam¹, O.A. Antipanova ${ }^{2}$, V.U. Babyshev², Tran ThiBich $\mathrm{Ngoc}^{3}$, Dao Thanh Binh ${ }^{3}$, \\ and G.A. Barysheva ${ }^{4 *}$ \\ ${ }^{1}$ Foreign Trade University, Hanoi, Vietnam \\ ${ }^{2}$ Tomsk Polytechnic University, 30, Lenin ave., Tomsk, 634050, Russia \\ ${ }^{3}$ School of Economics and Management of Hanoi University of Science and Technology, Hanoi, \\ Vietnam \\ ${ }^{4}$ International Scientific Educational Laboratory for the Improvement of Wellbeing Technologies of \\ Older Adults, Tomsk Polytechnic University, Tomsk, Russia
}

\begin{abstract}
The multinational corporations intensify activities in worldwide. For example, Vietnam's international integration has also changed rapidly with the trend of gradually entering the global supply chain and global value chain that help to create a powerful dynamic for national economic development. A part domestic enterprises is engaged either in outsourcing, or become a multinational corporations suppliers, but their role was unstable. The article also provides an overview of the unprecedented impacts of the COVID-19 pandemic on Vietnamese businesses, and the appropriate responses to reshape and strengthen corporations for processing and manufacturing industries. Special measures are given to be implemented at enterprises to prevent the risk of sickness among workers, including older workers.
\end{abstract}

Keywords: multinational corporations, domestic supplier, manufacturersupplier collaboration, supply chain, COVID-19 pandemic

\section{Introduction}

In April 2020, the COVID-19 coronavirus pandemic is in full swing, hitting all markets and countries. The impact of the spread of the infection will also affect the way companies and government agencies undertake digital transformation. This is the conclusion reached by the analysts referred to by TechRadar.

The UN issued a report urging countries to start creating a new economy, since the old one will no longer be the same due to the COVID-19 coronavirus pandemic.

The supply chain is not a new concept in all business sectors. It includes purchasing, securing input materials for the production process. Ongoing with production development process and international integration the concept is understood more broadly and involves

*Corresponding author: ganb@tpu.ru 
multiple stages, of which purchasing is just one of them. Chopra and Meindl [1] in their study given a view that supply chain consists of all parties involved, directly or indirectly, in fulfilling the customer's requests. It includes not only the manufacturer and suppliers, but also transporters, warehouses, retailers and even the customers themselves. Another concept of supply chain, according to Emmett and Crocker [2] was considered as the process that integrates, coordinates and controls the movement of goods, materials and information from a supplier through a series of intermediate customers to final customer. The key to the supply chain is that it links all activities between suppliers and buyers to final buyer in a timely manner.

Due geographically advantageous location, open policy, improving business environment and relatively low labour cost, since 1990s Vietnam has attracted record foreign direct investment and made spectacular progress in economic development. According to Ministry of Planning and Investment, accumulated to December 20th, 2019, the whole country has 30.827 valid projects with a total registered capital of 362.58 billion USD. The accumulated realized capital of foreign direct investment projects was estimated at 211.78 billion USD, equaling 58.4 percent of total valid registered capital (2020).

The experience benefited from development of East Asian economies and Southeast Asian countries was an advantage that helps Vietnam to shape and develop successfully it's the economy with export-led growth. In 2019, the export value of goods reached USD 264.3 billion doubled compared to 2013, in which the export proportion of foreign-invested enterprises accounted for $70 \%$, double compared to that of domestic enterprises.

The problem posed at current time is that although the export value seems to be high, however, the benefits gained from exports are not commensurate. For example, depending on foreign suppliers, the textile and garment, footwear and electronics industries in Vietnam can now participate only at a certain stages of production in the form of outsourcing for foreign brands or assembly of the final products of multinational corporations. Therefore, the manufacturing profitability of those sectors ranges from about 5 to 10 percent.

The appearance of large investment projects from multinational corporations such as Samsung, LG, Microsoft, Intel or Mitsubishi Heavy Industries etc. in Vietnam gives a golden opportunity to domestic enterprises to participate in supply chain. However, domestic enterprises have not really taken advantage of this opportunity and are still struggling so as they have not been able to determine their position.

The COVID-19 outbreak has brought unprecedented challenges, and has had significant impacts on Vietnam's economic development in 2020 and in the medium-term period. It sets out the task of reshaping the supply chain to ensure its sustainability and uninterrupted production and business of the country.

The COVID-19 has affected the protected population. Small and medium-sized enterprises where pensioners used to work are now closed. And here the question is whether they will be able to recover and continue their activities. But if there is no employer, then there is no job.

For example: in Russia "isolation" made pensioners the most powerless members of society. They cannot count on unemployment payments, even if they worked and were officially laid off, because pensioners, according to the state, have a pension.

The longitudinal method was used in the study to examine the dynamic structure of a reasonable ratio between domestic suppliers and multinational corporations manufacturers and evaluate reciprocal manufacturer-supplier relationship, using data from Thailand and Malaysia as countries in Southeast Asia that have similar production activities in comparison to Vietnam. The methods of data collection and analyzing data was also applied to determine the current situation of Vietnam's domestic suppliers and evaluation the impacts of supply chain disruption caused by Covid-19 pandemic on Vietnamese enterprises. 
Buyer-supplier relationships play an important role in supply chain management [3-4]. Supplier-buyer relationship plays an important role in supply chain management, in which the balance of power among the parties is a decisive factor in the success of manufacturersupplier collaborations. One company's dominance versus another is a function of relative dependence - that is, the difference between a company's dependence on its partner and its partner's dependence on the company.

Around the world, especially in East Asia and Southeast Asia, a significant increase in and development of strong, mutual and collaborative relationships between reliable foreign buyers (manufacturer) and domestic suppliers have witnessed the last three decades [5]. The supply-demand partnership between companies determines the network structure in manufacturer-supplier relations. Entrepreneurs are increasingly concerned about who has more power and the right to dominate in this structure [6]. In this structure, power is a key factor of partnership decision in supply chain. The power correlation between buyer and supplier determines the relationship level and the sustainability of the manufacturer-supplier relationship structure.

Research issues such as procurement strategies, supply chain and logistics, organization and supply chain structure, theoretical framework for buyer-supplier relationships are provided by Lysons K. and Farrington B., and described as core issues related to sourcing, purchasing, supplier relationships and partnering, supplier selection, etc [7]. Porter M. E. presented the Diamond Model with four determinants of national competitive advantage, and stated that the third broad determinant of national advantage is presence in the nation of related and supporting industries that are international competitive. International competitive home-based suppliers create advantages in downstream industries in several ways. That is, manufacturer cannot sustain without proper support of related and supporting industries. Related industries and supporting industries can produce inputs which are important for innovation and internationalization. They provide cost-effective inputs, but they also participate in the upgrading process, thus stimulating other companies in the supply chain to innovate.

The mentioned above studies based on theoretical and practical aspects confirmed the importance of downstream industries and supporting industries in the manufacturer-supplier relationship, as well as in enhancing the competitiveness of domestic suppliers. Therefore, appropriate policies aimed to strengthening the power of domestic enterprises and improving their ability to participate deeply in supply chain need further research [8].

The weaknesses of domestic enterprises are their limited capacities to meet the needs of assembly manufacturers in Vietnam. This problem, in our opinion, is partly expressed through: (1) the localization rate in the final product; (2) the number of supplier's in supply chain structure; and (3) small size and limited capital and backward technology.

A prime example of the current state of the automotive industry is the clearest evidence of the capacities of domestic suppliers.

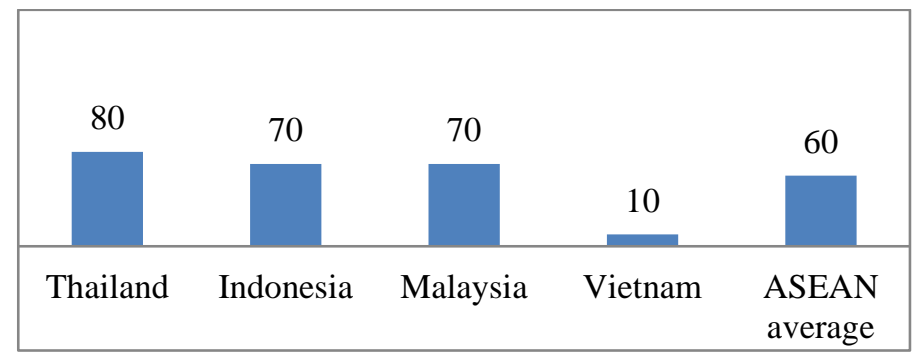

Fig. 1. Average localization rate of the automobile industry in ASEAN countries (in \%). Source: Ministry of Industry and Trade, Vietnam (MOIT). 
Currently, only a few Vietnam's suppliers can participate in the country that can enter into the supply chain of automobile assemblers. Compared to Thailand, the number of Vietnam's suppliers in the automotive industry is still very small. Thailand has nearly 700 tier 1suppliers, of which 46 percent are Thai's domestic companies, and about 1,700 tier 2 and 3 domestic suppliers, while those numbers in Vietnam respectively are nearly 150 and 83. Auto parts being manufactured in Vietnam are mainly labour-intensive and simpletechnology components such as glasses, inner tubes, etc [9].

In addition, 178 other tier 1 and tier 2 suppliers, which are overseas companies located in Vietnam, are involved in supply chain to maintain the operation of 21 assemblers. It means that Vietnam's automobile industry have to import up to 90 percent of auto parts and main raw materials for production of automobile components such as alloy steel, aluminum alloy, plastic beads and hi-tech rubber, etc. This fact explains why the localization rate in Vietnam's automotive industry remains lower compared to regional peers (Figure 1).

There is a contrast to enterprises reflected in low working capital and limited access to bank credit because they do not have enough mortgaged assets in Vietnam [10]. According to 2020 Vietnamese Enterprises White Book published by the end of 2018 the number of accounted for 97.2 percent of the total and has only 30.4 percent of the total capital of all enterprises. Therefore, due to limitation of working capital and credit access, the enterprises ability to implement technological innovation and production expansion is often restricted [11].

Outdated technology is one of the weaknesses of the domestic enterprises. The statistics of the National Department of Science and Technology Information in 2018 showed that among surveyed 10,994 manufacturing enterprises, only 879 ( 8 percent) use advanced technologies; 5,501 (50\%) have medium-technology machinery in use; and the rest 4,614 $(42 \%)$ use outdated technologies [12].

\subsection{Impacts of the Covid-19 pandemic on Vietnam's enterprises}

Vietnam's enterprises still depend on input sources from China. General Department of Vietnam Customs statistics showed that last year, from the total import value of \$ 253.07 billion in 2019, the import value of 7 key commodity groups from China was $\$ 56.73$ billion, of which import of computers, electronic products and spare parts worth $\$ 12.11$ billion USD; machinery, equipment, tools and spare parts - \$ 14.9 billion; textile, garment, leather and footwear materials and accessories of all types - \$ 11.52 billion; plastic materials and products - $\$ 3.99$ billion; iron and steel of all kinds - $\$ 3.4$ billion; chemical products - $\$ 3.23$ billion; mobile phones and accessories $-\$ 7.58$ billion. Outbreak of Covid-19 pandemic has disrupted imports from China and other countries into Vietnam.

\subsection{Impact of the Covid-19 pandemic on the aged population in enterprises}

IndustriALL Global Union believes that the health and safety of older people is within the scope of workers 'rights and employers' responsibilities. Neither the emergency caused by the COVID-19 outbreak nor the disease caused by a new virus changes these fundamental principles. On the contrary, they are more important now than ever. This includes providing information, education, training and providing workers with adequate protective equipment and equipment to perform safely their work. In addition, new specific laws or regulations could be enacted to combat the COVID-19 outbreak. The workplace must meet all the requirements of the current legislation.

Unions are pushing for the right of older workers to participate in decision-making on how to control the Covid-19 outbreak. This means that the Joint Occupational Health and 
Safety Committees and union representatives should be actively involved in the design, implementation and monitoring of all measures taken.

\section{Results and discussion}

Many Vietnamese businesses suffer due the disruption of the supply chain. A recent survey conducted by International Stem Cell Corporation in late March, 83 percent of companies in the physical value chain in Vietnam (retailers, shippers, traders and producers) have been suffering from supply chain break over the past two months; 47 percent of them faced difficulties with Chinese supplies, largely involved in raw materials. In April 2020 was conducted a rapid assessment of the severe impacts of the Covid-19 pandemic with 700 enterprises and business associations from 46 provinces/cities across the country, including a large number of enterprises operating in nearly all social and economic sectors. The results were as follows.

i. Market narrowing is the main impact of the pandemic on the enterprises. 83.30 percent of the enterprises said that they have lost or had less consumption market; the group suffer from the most serious impact is the domestic private enterprises with 85.17 percent;

ii. Lack of capital/cash flow for doing business: 52.47 percent of enterprises said that they were short of capital or cash flow for doing business due to the impact of the pandemic on production and business activities have been affected most severely ( 58.61 percent)

iii. Lack of supply of input materials: 45.14 percent of enterprises said that they had a shortage of input materials for production and business activities of enterprises, of which FIEs suffered from the highest shortage (58.33 percent).

iiii. Narrowing down the labour force: 43.95 percent of enterprises had to shrink the labour force due to the impact of the pandemic, in which the private sector had to cut down the largest number of workers (48.56 percent).

The interruption of external supplies, though occurred only in the short term, has a serious impact on production and services in Vietnam, slowing its economic growth, and the consequences will last for a long time when the problem of the supply chain realignment has not been solved globally.

Studying the status of domestic enterprises, it can be concluded that the above weakness are the barriers that prevent domestic suppliers from participating deeply in the supply chains and getting expected value added. Moreover, domestic enterprises weakness even increases the import dependence and it is easily exploited by foreign investors to adopt a transfer pricing system to avoid paying taxes and achieving high profits by raising the price of imported equipment's, technology, raw materials produced by their overseas companies located in other countries [13]. In order to solve the problems, it is necessary to take comprehensive measures addressing creating domestic suppliers' power and balancing supplier-buyer relationship.

The review and analysis of the situation in international companies shows that currently the connection between them has been relatively limited due to reasons being on both sides..

Domestic enterprises, in addition to the aforementioned weaknesses, complained that in connecting with they encountered the following difficulties: (1) lack of marketing and market research skills and experience of developing customer relationship; (2) lack of information on the requirements of multinational corporations and international standards applied in certain industries; (3) having the problem with access to capital and deal with investment risks at renovating technology for meeting quality standards and enhancing firm's competitiveness.

Addressing these issues often results in increased investment costs that foreign investors do not want and often try to elude. 
In order to develop supporting industries and improve its effectiveness, joint efforts should be focused on measures such as: (1) updating and adjusting the list of priority supporting industrial products to suit real market needs; (2) allocating sufficient funds to effectively implement The National Supporting Industries Development Program for the period 2016-2025 and building preferential credit packages for development of priority supporting industries; disseminating information on the supporting industries policies to attract domestic and foreign investment in the supporting industries development; (3) building a database of domestic supporting industries and suppliers to promote the connection between Vietnamese domestic suppliers and multinational corporations manufacturers wishing to find suppliers in Vietnam, and creating connection programs on expanding links between domestic enterprises and multinational corporations manufacturers.

Over the past three decades, emerging market economies have depended heavily on export-led growth as a driver for economic development. However, at current time, the hope will be disappointed by the fact that the conditions for supporting export growth have exhausted due to the impact of the Great Depression and other fluctuations. Lack of shortage of demand and intense competition between emerging market economies, export growth could not meet the whole emerging market economy. The solution is to gradually shift to domestic demand-led growth, regarding the exhaustion of export-led growth. Thus, considered that in parallel with national strategies on attracting export-oriented, it is necessary to ensure the harmony between export growth and investment in development of high value added products and services aimed at strengthening import substitution, using domestic raw materials, developing supporting industries and training domestic force.

Today, there are challenges and threats caused by geopolitical reasons and global fluctuation that severely disrupts supply chain. Some leading economies, having their own protection policies, hinder globalization and global free trade process. Beside this, disasters, for example, the global COVID-19 pandemic have caused enormous financial and socioeconomic losses in most countries around the world, including disrupting supply chain.

Some researchers considered that before the COVID-19 pandemic there have been a series of non-pandemic-related factors have caused global business managers to re-evaluate how to optimize their supplier relationships. These include: (a) rising labour costs in China, Taiwan and other major Asian production centers. This development already has motivated the relocation of certain product-component manufacturing or sub-assembly into lower-cost nations such as Cambodia, Vietnam and other Asia-Pacific nations; (b) continuing quality control and related risk problems of food and pharmaceutical safety; (c) increasing supply chain complexity and loss of business control; (d) growing resistance of family members to live in highly polluted or politically unstable countries; and (e) re-examining the costs and efficiencies of multi-tiered supply chain structures.

COVID-19 pandemic has revealed the vulnerabilities of complex supply chains built on the principle of lean manufacturing, accelerated and deepened supply chain restructuring. Therefore, by Yosie T.F., multinational corporations are examining different options to reduce the rising risks and costs from complex supply chains in a post-pandemic world, including: regionalizing supply chains, localizing their suppliers closer to manufacturing operations; hedging strategies aimed at relocating supply chains and diversifying raw material sourcing or supply chain components and redefining the customer-supplier relationship that expands joint opportunities for co-innovation and smarter production, talent recruitment and retention, business continuity when faced with periodic disruptions, and longer-term competitive pricing; building longer-term business relationships with fewer suppliers.

Enterprises should introduce special measures to prevent the risk of sickness among workers, including older workers: occupational health at work and at workplaces; treatment 
of patients or persons with suspected coronavirus; individual protection means; providing adequate social protection.

\subsection{Impact on the workplace.}

Among the main drivers of direct impact of COVID-19 is the need to manage the transition to a teleworking model and the willingness to increase the number of sick leave. The solution to these challenges can be the creation of flexible digital jobs. The actions taken will differ from organization to organization, but they should be based on the following principles: to protect employees and increase the level of opportunities available to them; meet the basic needs of customers; and maintain business continuity. For example, there is an urgent need for virtual messaging and doctor visits in healthcare.

Although COVID-19 is the catalyst for the immediate deployment of the Elastic Digital Workplace.

\section{Conclusion}

Vietnam's economy is facing great challenges, but there are many opportunities for new inflows related to reshaping supply chains after the pandemic. Since 2019, in order to avoid new tariffs on goods exported from China to the United States and the tendency of protecting national economy appeared in in international relations, more arguments are put to pursue an alternative market for production due to unpredictable events and rising labour cost in China, some multinational corporations have taken steps to expand supply chain in Vietnam. The supply chain disruption caused by the pandemic has accelerated this process. Therefore, along with the post-pandemic recovery of socio-economic activities, Vietnam needs to continue improving the investment environment, developing and upgrading the infrastructure network and having equal policies to attracting domestic investors, ensuring the balance of power of the manufacturer-supplier relationship and equal development opportunities for both domestic enterprises.

The COVID-19 pandemic is having a severe impact on the world's population. During this time, in many countries, older people face the greatest number of dangers and difficulties. While all age groups are at risk of contracting COVID-19, older people, if infected, face a significant risk of developing severe disease. It follows from this that special precautions should be taken in enterprises.

The reported study was funded by RFBR project number 19-310-90050.

\section{References}

1. S. Chopra, P. Meindl, Supply Chain Management: Strategy, Planning and Operation. 6-th Edition (2004)

2. S. Emmett, B. Crocker, The Relationship-Driven Supply Chain: Creating a Culture of Collaboration throughout the Chain. Copyrighted materials. Part 1 (2006)

3. D.C. Bello, C. Chelariu, and L. Zhang, The antecedents and performance consequences of relationalism in export distribution channels, Journal of Business Research, 56(1), 1-16 (2003)

4. M. Sako, and S. Helper, Determinants of trust in supplier relations: evidence from the automotive industry in Japan and the United States, Journal of Economic Behavior and Organization, 34(3), 387-417 (1998) 
5. F. Habib, M. Bastl, C. Pilbeam, Strategic responses to power dominance in buyersupplier relationships: A weaker actor's perspective, International Journal of Physical Distribution \& Logistics Management, 45, 182-203 (2015)

6. L. Kenneth, B. Farrington, Procurement and Supply Chain Management, 9th ed. (2016)

7. J.H. Dyer, and H. Singh, The relational view: cooperative strategy and sources of interorganizational competitive advantage, Academy of Management Review, 23(4), 660-679 (1998)

8. M.E. Porter, The Competitive Advantage of Nations. Harvard Business Review, March-April, 11-19 (1990)

9. E. Rugraff and M.W. Hansen. (Eds) Multinational Corporations and Local Firms in Emerging Economies (Amsterdam University Press, Amsterdam, 2011)

10. Tony Cragg, Tom Mcnamara, Irena Descubes, Frank Guerin, Manufacturing enterprises, Network Governance and Global Supply Chains, Journal of Small Business and Enterprise Development (ahead-of-print) (2019) DOI: 10.1108/JSBED10-2019-0334

11. L. De Mello, Foreign Direct Investment-Led Growth: Evidence from Time Series and Panel Data, Oxford Economic Papers 51(1), 133-151 (1999)

12. Ohno, Kenichi. Vietnam-Japan Monozukuri Partnership for Supporting Industries. For Leveling Up Vietnam's Competitiveness in the Age of Deepening Integration. Vietnam Development Forum. (2008)

13. Ngoc, Tran Thị Bích and Binh, Dao Thanh (2019), Vietnam's Electronics Industry: The Rise and Problems of Further Development, Humanities \& Social Sciences Reviewse, 7(4), 1-12 (2019) Doi: https://doi.org/10.18510/hssr.2019.741 